\title{
Integrating the Service Paradigm into Procurement Practices in Ghana
}

\author{
Mawuko Dza ${ }^{1}$ \\ ${ }^{1}$ University of Education, Winneba, Ghana \\ Correspondence: Mawuko Dza, University of Education, Winneba, Ghana. E-mail: mdza@uew.edu.gh
}

$\begin{aligned} & \text { Received: September 4, } 2017 \\ & \text { Accepted: September 26, } 2017 \quad \text { Online Published: October 30, } 2017 \\ & \text { doi:10.5539/par.v6n2p58 }\end{aligned}$ URL: http://dx.doi.org/10.5539/par.v6n2p58

\begin{abstract}
This paper investigates how an integration of the concept of service into public procurement practices in universities in Ghana could lead to performance improvement. With samples drawn from procurement practitioners of public universities in Ghana, the study adopts a qualitative approach based on the constant comparative analysis of interview data; deriving categories from composite concepts. At the end of the analysis process three 'categories' emerged - procurement practice, resource integration and networking, and information support systems for procurement practitioners. A careful evaluation of these 'categories' show that whereas an integration of the concept of service dominant logic into procurement practices could improve procurement performance in public universities in Ghana, bottlenecks such as minimal resource integration and networking; inadequate information support systems; and prohibitions on customer-supplier relationship building affect performance improvement. These findings are significant because they contribute to the body of knowledge in a study area known for its paucity of empirical information.
\end{abstract}

Keywords: procurement, service paradigm, operand resources, operant resources, constant comparative analysis, service dominant logic, Ghana

\section{Introduction}

Researchers in services and service science suggest that to properly understand the term "service", require a new way of thinking (Spohrer, et al; 2008). Service, as used in service dominant (SD) logic connotes the application of competences, knowledge, and skills for the benefit of another entity (Vargo \& Lusch, 2006). The concept is built on the premise that stakeholders form an integral part of the value-creation process; implying that value is a co-creation between the supplier and the consumer (Vargo \& Lusch, 2006). In other words, value creation involves a network of interactions by people, institutions and technology to co-produce service offerings; exchange service offerings; and co-create value (Lusch, Vargo, \& Tanniru, 2010). SD logic's service-for-service and resource-integration perspective represents a shift in thinking away from the dyadic notions of production and consumption towards the co-creation of value through complex, interactive, resource-integrating networks (Vargo and Lusch, 2010). The logic places emphasis on intangible, dynamic resources as inputs for co-created value (Gummesson, et al., 2010). This viewpoint is in stark contrast with the dominant view, in which the supplier is seen as operant resource acting on the passive consumer who is considered as an operand resource (Lusch \& Vargo, 2012).

It is important to note that the role of SD logic is growing in interest within public procurement. This development is as a result of similarities of the foundational premises of SD logic with strategic procurement practices in public organizations (Dza, 2013). For instance, just as in SD logic, it is argued that the driving force of an effective procurement system is collaboration. Thus an effective procurement system requires strong collaboration among suppliers, customers and all other participants in the value chain (Horvath, 2001). Indeed, the issue of customer-supplier collaboration has attracted a growing body of academic research in recent times. This increased attention reflects the growing awareness of the link between effective management of such relationships and organisations' performance (Terpend et al. 2008).) It has become imperative to foster an effective customer-supplier relationship because the lack of it leads to increases in procurement costs through multiple contracts administration; the pressure of monitoring many suppliers' performance; and the need for continuous education of suppliers on organizations' processes and requirements, among others (Mandiyambira, 2012). The issue of collaboration is reinforced by the resource-based view (RBV), which provides theoretical support for the significance of collaborations as a solution to exploit complementary capabilities to achieve competitive advantage. The theory argues that firms seek to develop competitive advantage by building 
relationships with other firms, and having a sound understanding of what the partner firm can bring to the collaboration (Barney, 1991).

Besides building strong and long-term relationships and collaborating with stakeholders to enhance organizations' efficiency, the adoption of information support system in public procurement has also become a critical resource for organizational growth and development (Dza, 2013). This view is supported by the concept of SD logic, which suggests that with improvements in information, and communication technology, the focus of businesses has gradually been shifting from physical goods as units of output to intangibles such as knowledge, competences, skills, and information. Hence, adopting information systems support in public procurement enable stakeholders to improve their individual and collective well-being by exchanging the service that they can provide to others for the service they need from others much faster and efficiently (Vargo \& Lusch, 2006). However, despite its importance, research suggests Ghana's public procurement system make minimal use of information support systems (Dza, et. al., 2013). This phenomenon according to the World Bank is attributable to the fact that African governments have been slow in putting in place the necessary information systems' capacity required; again, the deployment of information technology infrastructure as well as lack of mass internet access; and the use of antiquated administrative cultures (Thomas et al., 2007).

Notwithstanding the significant contribution of "service" to the global economy, studies, show that the concept has attracted little scholarly research (Bloom, 2005). Currently, there is no known research carried out with the objective of evaluating the relationship on performance of integrating SD logic into procurement practices in Ghanaian Universities. This paper, therefore bridges the knowledge gap by successfully integrating SD logic into procurement practices in universities in Ghana, thereby contributing to the body of knowledge in a study area notable for its paucity of information.

\section{Public Procurement in Africa}

Over the years, a number of African countries requiring financial transparency, fairness, and efficiency in their procurement processes have undertaken procurement reforms. These reforms are important feature of anti-corruption effort that seeks to promote good governance through improved procurement performance (Thai, 2008). For the reason, it has become imperative for organisations and institutions in Ghana and other African countries to put in place innovative structures that incorporate monitoring and control systems in public procurement (Wittig, 1999). However, in some African countries, these innovative structures are hindered by challenges of national laws. For instance in Sierra Leone, the National Public Procurement Authority in its 2005 report outlined several challenges impinging the operations of the Authority. Some of them include: inadequate governmental funding, incompetent and inadequate staff, organizational and logistical limitations among others. The report suggested among other things that, the law could only achieve its objectives if there is a concerted effort by all stakeholders, backed by very firm commitment and political will and adequate budgetary support to streamline and improve public procurement procedures in that country (NPPA Annual Report, 2005).

\section{Procurement in the Public Sector of Ghana}

In the past few decades, policy makers in Ghana did not see public procurement as contributing strategically to national growth and development. This perception changed in the late 90s when financial donors mounted pressure on the government to be more transparent in public procurement and public financial management. The pressure led to the enacted of the public procurement act, (Act 663) in 2003 (Anvuur \& Kumaraswamy, 2006). The act provides for the establishment of a public procurement board (PPB) as a legal corporate entity. Under the provisions, public entities are mandated to establish tender committees that provide guidelines for concurrent approvals, awards and management of contracts to predefined value thresholds (Ministry of Finance, 2003). The tender committee is mandated to refer any procurement exceeding its value threshold to a tender review board. The tender review board reviews all procurement activities for compliance with the Public Procurement Authority (PPA); provides concurrent approval or otherwise of procurement referrals; hears complaints and refers unresolved issues to the board. Under the Act, all procurement contracts must be tendered on an open competitive basis, except otherwise provided for in the Act. Restricted tendering may be justifiable only on grounds of providing greater economy and efficiency and subject to the approval of the board (Ministry of Finance, 2003).

\section{SD Logic}

SD logic represents a shift from an emphasis on the exchange of physical resources, usually tangible inert resources, to an emphasis on knowledge, skills and competences - dynamic resources that act upon other resources to create value (Vargo \& Lusch, 2006). Service in this context involves at least two entities, one applying the competences and another integrating the applied competences with other resources and determining 
the benefits (Normann, 2001). SD logic draws on the proposition that value creation is a collective effort between the firm and the customer (Prahalad \& Ramaswamy, 2004). In other words, value is created when a customer interacts with the resources and capabilities provided by the relationship with the firm/supplier and other providers of resources (Lusch \& Webster, 2011). The logic suggests that it is the responsibility of firms to ensure that their value propositions appeal to stakeholders. It is also the firm's responsibility to assure that the value proposition is communicated to, and understood by the entire network of stakeholders (Lusch \& Webster, 2011).

SD logic is built on ten foundational premises (FPs) (Vargo \& Lusch, 2008). FP1 argues that the central tenet of the logic is that, service is the fundamental basis of all exchanges. The logic suggests that, all economies irrespective of the activities they engage in are service economies because they depend on the application of knowledge and competences to be productive (FP5). SD logic acknowledges that the direct service-for-service exchange is often characterized by complexities in the business environment as a result of which indirect exchange masks the fundamental basis of exchange (FP2). The process of value creation within and between service systems becomes increasingly complex as intermediaries develop. These business-related intermediaries, such as goods, money and organizations, maintain important roles in facilitating the process of exchange. In other words, goods are seen as distribution mechanisms for service provision, rather than primarily for exchange and value creation (FP3). SD logic also establishes the importance of operant resources such as knowledge and competences as the fundamental source of competitive advantage (FP4). The logic intimates that value-creating resources are not confined to the firm. Suggesting that customers, suppliers, and other stakeholders constitute operant resources and hence contribute to value creation. More broadly, SD logic contends that value is always co-created with customers and others through interactions and collaborations (FP6). Therefore, firms alone cannot create and deliver value but can only offer value propositions (FP7) and provide service as input to its realization. In essence, firms have exchange value, which when harnessed by the customer becomes value-in-use. SD logic further argues that because service is defined in terms of customer-determined benefits and co-created, it is inherently customer oriented and relational (FP8). Ultimately value is phenomenologically and contextually derived by the service beneficiary (FP10). In other words, value is not created until a beneficiary of the service, often the customer, integrates and applies the resources of the service provider with other resources, in the context of its own specific available resources (FP9).

\section{SD Logic and Procurement Performance}

Procurement performance provides a basis for an organisation to assess how well it is progressing towards achieving its predetermined objectives; identifying areas of strength and weaknesses; and deciding on future initiatives with the goal of initiating performance improvements actions (Van Weele, 2006). To improve upon their performances firms are building long-term relationships with suppliers, and are hesitant to rely on untested suppliers. As firms emphasize collaborative relationships with key suppliers, buyer institutions are using supplier evaluations to ensure that their performance objectives are met (Prahinski \& Benton, 2004). These views are consistent with FP7 of SD logic, which explains that because firms cannot create value independently but can only offer value propositions, it is important for actors in business engagements to collaborate by sharing operant resources in order to jointly create value. Forging long-term relationships in a competitive business environment helps firms achieve superior performance by reducing cost, improving quality, and enhancing customer responsiveness (Christopher \& Gaudenzi, 2009).

Currently, Ghana's Public Procurement Act (ACT 663) forbids the public sector from having key suppliers although research has shown that having key suppliers is important an important cost cutting measure and improves performance (Burt, et al., 2003). Indeed, there is evidence to suggest that most firms' performance improve as a result of strong relationships built with suppliers over the years (Monczka, et al., 2002). On relationship building, networking and resource integration, the study found that public universities in Ghana do somewhat integrate their resources to a certain extent and engage in networking within their institutions. The challenge is that these Universities being autonomous entities compete against each other for recognition especially in areas of innovation and creativity, hence has little motivation to integrate their resources and engage in networking (Dza, 2013). Relating this to SD logic, the concept suggests that value is created through collaborative effort between firms and consumers through the process of resource integration, networking and application of competences (Vargo, et al., 2008). Therefore proper management of supply chain interfaces that connect the individual actors and exchange, and leverage knowledge across the network is essential because the strength of the relationships at the interfaces can become the basis for building organizational reputation and creating an environment more conducive for co-operation and knowledge sharing (Christopher \& Gaudenzi, 2009). 


\section{University Education in the $21^{\text {st }}$ Century}

Universities at their inception were essentially regarded as elitist institutions, open only to selected members of society (O'Brien \& Deans, 1996). However, in the present era of knowledge driven economies, the role of university education has become crucial to the overall socio-economic development of nations (Makkar, et al; 2008). Thus universities are service providers whose rationale is to transform students' knowledge through relationships and other exchanges among students and university faculty (Spohrer, et al; 2007). Public universities like other educational institutions are generally conservative, risk averse and slow in response to market needs. Traditionally universities have resisted any kind of interference from external stakeholders, especially employers and the general business community (Al-Turki, et al, 2008). But with increasing competition on global job markets, there is a realization that either universities adapt to the changing trends or risk being out-run by others in terms of competitive advantage (Al-Turki et al., 2008). Responding to the challenge, many universities are moving away from their hitherto rigid stance towards stakeholder engagement to a more flexible relationship. These steps have become necessary as the gap between knowledge offered by universities and knowledge and skills required on the job market is widening (Al-Turki et al., 2008). Additionally, the rising cost of university education (Immerwahr \& Johnson, 2007) means stakeholders would continue to demand value for money (Comm \& Mathaisel, 2008). Thus, universities are now under pressure to minimise operational costs and improve operational efficiency by channeling resources only into activities that create value for their customers and other stakeholders (Goldsworthy, 2008).

\section{Methodology}

The paper adopts a qualitative approach with philosophical underpinnings from symbolic interactionism and the interpretivist paradigm. Since the information required had to be elicited from experts in the field of procurement, a non-probability sampling approach was deemed the most appropriate. The sample was drawn from procurement practitioners from public universities in Ghana. Having identified a defined group of respondents, the author proceeded with a snowball sampling method. This approach was used to identify cases of interest from participants who knew other practitioners who could provide rich information on the phenomenon under investigation (Cope, 2005). Although this approach lacks respondents' representativeness, it is the most suitable for the issue under investigation because respondents tend to form their own unique social circles and provide rich information. Similar to most qualitative approaches, the author's use of multiple data sources for this paper led to data triangulation in areas of source, location, expertise, and position, which has addressed the potential problem of trustworthiness of research findings (Yin, 2009).

\subsection{Data Collection and Analysis}

Data were collected through open-ended interviews and observations of procurement practitioners from five public universities in Ghana. All interviews were audiotape recorded under the express consent of participants. Identified concepts were built into composite concepts through constant comparative analysis (Strauss \& Corbin, 1998). Selective coding was then used to build composite concepts into categories of description or themes. Data collection and analysis were done almost at the same time. This approach is significant as it informed the next interview and facilitated constant comparison of concepts (Strauss \& Corbin, 1990). The constant comparative approach also enabled interview texts to be analysed line by line, with provisional themes noted, and subsequently compared with other transcripts in order to ensure consistency and identify negative cases (Goulding, 2005). Then emerging concepts were used to classify the data separately and connections made between these concepts providing the basis for a fresh description (Dey, 1993). After the conceptualisation phase, concepts that pertained to the same phenomenon were grouped together to form categories. At the end of the process three categories namely: procurement practice, resource integration and networking, and information support systems for practitioners emerged. The author upheld the confidentiality of respondents by using pseudonyms of 'PbU1' to 'PbU5' to represent participants and their respective universities.

\subsection{Results and Discussions}

The discussions of the findings based the three categories that emerged during the comparative analysis process and some researcher abstractions.

\subsubsection{Procurement Practice}

On procurement practice, practitioners intimate that all public universities are by law mandated to have a register of suppliers and prospective suppliers. However, the study revealed that not all practitioners used the register for the purpose intended. For instance whilst a section of practitioners indicate that they use the register as a database to invite prospective suppliers to bid for contracts, others explain that the supplier register is compiled 
in order to meet the requirements of the PPA. PbU2 explains: "we use the supplier register to invite our preferred suppliers...we have preferred suppliers because we have worked with them for some time and know their competences and shortcomings. Bringing in new suppliers tend to be problematic because of the fear that they may not deliver to our taste or standards". When asked whether having preferred suppliers is not in contravention of the public procurement law, this is the practitioner's response:

It can sometimes, but if you try bringing new suppliers, these suppliers may end up bringing problems for you. There was an instance where a supplier brought a sample of a printing work that was of very good quality. So we decided to give him a chance, and requested that he brings his list of documentations. The supplier brought the first sample of which we were not satisfied. He brought the second sample which still had quality issues. So we had to go back and start the process all over again with our preferred supplier. As you can see, this resulted not just in time being wasted, but also has financial implications for the university, and at the end of the day the procurement department is blamed for being incompetent.

Commenting on his university's position on key/preferred suppliers' status, PbU1 indicates: "the procurement law forbids public institutions from building buyer-supplier relationships therefore any institution that gives undue favour to some suppliers over others will be perpetuating an illegality". PbU1's position is affirmed by PbU5: "we have registered suppliers, but we don't have preferred ones. All we do is that, we advertise for suppliers to express interest by submitting tenders. Suppliers who meet our requirements are awarded the contract". Thus through close relationships with suppliers, institutions are willing to share risk and reward, encourage mutual planning and problem-solving efforts, and maintain the relationships over a longer period of time (Li et al., 2007).

In relation to university/supplier value co-creation, practitioners generally agree that value results from a joint or collaborative effort between the university and supplier firms. Practitioners also corroborate the fact that supplier firms offer value propositions of which when ignored by the university would lead to no value being created. PbU2 explains: "because value is created during the exchange process, and the suppliers don't produce and consume themselves, they produce and supply so that exchange takes place and value is jointly created between the two". Practitioners explain that a supplier firm's knowledge of the university, and the quality of relationship required to gain shared access to the university's privileged resources are directly related to the quality of value propositions that the supplier firm can offer. The issue of suppliers offering value propositions receives this response from $\mathrm{PbU} 1$ :

Suppliers are providing tangible resources fine, but these tangible resources that they are providing to us did not come by its own sake. It is this application of the same operant resources by suppliers that resulted in the production of the goods or services. So to say that they only offer operand resources, to me is an insult on their intelligence. I do agree that suppliers propose value. It is like they make the offer and the university accepts the offer, takes delivery notes indicating that you have accepted the offer. I also agree that if the university fails or refuses to accept the offer, value will not be created. My concern is for us to recognise that suppliers also make use of operant resources.

Visibly incensed by some of the provisions of the public procurement law, PbU2 explains the significance of understanding that value co-creation comes about through joint efforts and this joint effort is facilitated by the relationships among the actors of a business engagement. PbU2 reiterates her university's stance on building some form of covert relationship with some of its suppliers explaining that:

...since both parties understand that value is not created by the supplier alone, neither is it created by the customer alone. And that value is jointly created by the parties involved, this will improve the quality of goods and services provided, and could also lead to strong relationship building. Surprisingly, sometimes we make this position known to our suppliers...what if we decide not to buy your supplies or services, and no other organisation buys it? Will you get any value for your items? It is important that parties in business come to the realisation that each of them provides something special that together lead to a jointly created value.

Taking a retrospective look at the discussions on value co-creation, one is tempted to conclude that irrespective of perceived bottlenecks of the current procurement system, there is an overwhelming perception that, if universities and suppliers understand and accept that value creation is a joint effort, procurement performance will improve significantly. This is because they would strive to produce and supply their best especially in areas 
of quality and delivery time. SD logic's position on operant resources and value co-creation is explained in FP4 and FP6 respectively. FP4 stipulates that operant resources are the fundamental source of competitive advantage. In other words, firms require knowledge, technology, information, skills and competences in order to act upon operand resources to create value. With regards to value co-creation, FP6 states that the customer is always a co-creator of value. It is therefore important that suppliers and universities collaborate so as to jointly co-create value.

On the question of who determines value, whilst PbU4 suggests that "value is created by both the supplier and the university", he disagrees with the assertion that value is ultimately determined by the university, explaining that, "I think both the supplier and the university determines value because they jointly created it through their efforts and collaborations with one another". Contrary to the views of PbU4, FP10 of SD logic argues that the beneficiary always determines value. This argument stems from the fact that the value of 'everything' is experienced only when that 'thing' is accepted and put to use by the consumer/beneficiary.

\subsubsection{Resource Integration and Networking}

It is significant to acknowledge that modern competition is based on the value co-created by the entire network, from raw material extractors to end-users, through dynamic, multi-party dialogue, knowledge exchange, and utilisation of operant resources. Networks that provide end-users with better service experiences, gain perceptions of higher value-in-use, which in turn result in higher levels of collaborative value-creation behaviours such as loyalty, and further dialogue with network members (Tokman \& Beitelspacher, 2011). Thus value is created when customers and suppliers engage in dialog and interaction during product design, production, delivery, and consumption (Yazdanparast, et al., 2010).

University/supplier integration is the level to which a supplier firm can partner with the university to structure their inter-organisational strategies, practices, procedures, and behaviours into collaborative, synchronised, and manageable processes in order to achieve their requirements (Zhao et al., 2011). University integration allows suppliers to access the institution's information, share knowledge, pursue joint development activities, speed up decision processes, reduce lead times, and improve performance (Narasimhan \& Kim, 2002). Such integration is critical in helping suppliers not only to acquire information about the university's requirements, but also gain a better understanding of their preferences and needs (Swink \& Nair, 2007). It is significant to understand that SD logic recognises the fact that when an institution is being supplied with products or services, these supplies enter into some form of value creating process where it is integrated with other resources to provide the flow of service (Lusch, 2011).

According to practitioners, the rigidity of the current procurement system makes it impossible for resource sharing and networking. They argue that the public procurement law as it stands now "does not encourage supplier engagement and militates against relationship building with suppliers". PbU2 points out: "the quest for transparency and the desire to curb corrupt practices in public procurement has lead to stringent policies on procurement which I think may rather retard the improvements that we are all yearning for". Networking with partners and stakeholders has been an important business concept with many success stories in the literature. PbU5 explains:

...we all hailed the current procurement system thinking it was something great. Of course some aspects of the law are fantastic but other areas give us 'headache'. Can you imagine a procurement policy that discourages knowledge and information sharing, and networking with supplier firms on the pretext of transparency and fighting corruption? I think the intentions for such a policy might be good, but was not thought through properly.

$\mathrm{PbU} 4$ commenting on the issue states: "the law forbids buyer-supplier relationship, so where there is the need for interaction this must be sanctioned by the procurement committee, the entity chairperson or even the PPA. These engagements are sanctioned especially when contracts have been awarded, and there is expediting to ensure that the supplier fulfils the contract terms". When asked whether there are indeed any such prohibitions in the procurement law, $\mathrm{PbU} 4$ explains:

Even if it is not in the procurement law, the PPA has made it official and who are you to challenge them. Challenging the law is not the problem, but because the majority of practitioners and suppliers have come to accept it, it has become a norm and anybody that speaks against it becomes a deviant. But if you ask me now whether the current procurement system or policy or whatever you choose to call them have reduced corrupt practices in public procurement, I can boldly tell you, 'no'. 
Internal university integration is the degree to which the different internal functions of an institution collaborate with one another, coordinate intra-university activities and decisions strategically and form cross-functional integral relationships (Zhao, et al., 2008). Structuring institutional activities into cooperative processes facilitate the acquisition and transfer of institutional knowledge into specific designs, processes, and final products, which in turn leads to a more connected and coordinated internal response to marketplace changes and disruptions (Flynn, et al., 2010). Greater use of collaborative methods allow universities to reduce transaction costs, and benefit from negotiated lower prices and better delivery and warranty conditions for the procurement of many goods and services (Terzi \& Posta, 2011).

Practitioners' response to inter-departmental activities' integration vary as PbU3 explains: "We work together in order to achieve the institution's goals. The working relationship among departments is interactive as departments always call on the procurement unit anytime there is the need to procure goods or services for their departments". Responding on the same issue PbU5 explains:

Activities are well integrated in our university because the stores department liaises with procurement to get every single need of every single user department. This enhances uninterrupted flow of supplies to user departments. Sometimes there may be shortages at the departments just because the heads of department did not raise or bring a requisition to the stores for replenishment. I can say that because of the level of integration in the university among departments, we are able to identify common needs for some of the departments and this saves the university some money.

Other practitioners admitted to occasional misunderstanding among integrating departments. PbU2 explains:

Our activities are well integrated with the rest of the departments. However, some departments complain that sometimes we don't involve them in making decisions that affect them. But in actual fact, what happens is that, some heads in the user departments go out on their own and source for items without the procurement department's concern and brings the invoice to procurement insisting that that's the item they want. Of course, we can't grant them their wish since they did not follow due process.

The practitioner does not think such occasional glitches affect the smooth running of the university arguing; "this is a one-off thing. It doesn't happen all the time, and like all human establishments there are bound to be occasional hitches here and there. When they happen we look for solutions and try to prevent their reoccurrence".

Regarding the question of whether the procurement department is part of a network of universities that collaborates by pulling resources together in order to have good deals from suppliers, PbU3 responds: "I think you're talking about purchasing consortia. These arrangements are foreign to us. So at the moment we have nothing like that, maybe they'll come up in future as we continue to develop our procurement systems". PbU5 intimates that under the current public procurement system, every university is a separate entity with well laid down structures for procuring. PbU5 explains further:

Every entity has a head, which is the head of the university. The head of entity together with the procurement committee have been given legitimate authority to procure goods and services. So to me, forming buying consortia with other universities for the sake of having a good bargaining power and also benefiting from quantity discounts will amount to perpetuating an illegality. I think the procurement law does not give us that leverage, and each individual university must act based on its needs and priorities.

Responding to the issue of resource sharing among universities, PbU1 explains:

I'll say there isn't any formal resource sharing between my university and others. What I can say is that sometimes the PPA organises workshops and seminars for procurement staff. During such encounters, ideas and experiences of procurement professionals are discussed and shared. The problem with these meetings is that they seldom happen.

The practitioner explains that in these workshops new ideas are shared between resource persons and practitioners from various public institutions. PbU5 on his part expresses dissatisfaction about the fact that public universities are being run on grounds that they are self sufficient because of their autonomous status. "No university wants to collaborate in terms of sharing resources with another. The heads of the universities want to claim credit for being the first to introduce one innovation or another". Asked why other universities knowing that their counterpart(s) have come out with some innovations will not approach them to discuss the possibility 
of collaborating and sharing each other's distinct resources for their mutual benefit, PbU5 explains:

I think this attitude is endemic in the Ghanaian society. We think by sharing our knowledge and experiences others will have access to what used to be our monopoly. Frankly, I've not seen any university approach us to discuss issues on collaboration or resource sharing for our mutual benefits. But I think our university is also guilty as we've not made any effort to reach out to other universities. This may sound ridiculous, but the only things we share are our academic gowns during students' matriculation and congregation.

$\mathrm{PbU} 2$ although acknowledges the significance of resource sharing and networking does not see anything wrong with the current practice where universities stick to the resources they have and use them for their own benefit. The practitioner explains:

All public universities are autonomous entities, and are all given government subventions periodically. I think it is incumbent on the universities to be creative and innovative and come out with credible ideas that will move their universities forward. The ability to do this shows leadership and the ability to think outside the box. I don't think Ghanaian universities are hostile towards each other. There is a friendly relationship among all universities. We sometimes share ideas, but ultimately it is the university itself which must be responsible and chart the path it wants to follow.

The issue of resource sharing is an important concept of SD logic. Indeed FP 9 points out that all social and economic actors are resource integrators because value co-creation results from networks of collaborative relationships where one unique resource is exchanged for another. FP1 stipulates that the application of operant resources - knowledge, skills, technology, competences are the fundamental basis of exchange, and that service is exchanged for service. This assertion is supported by FP5, which argues that all economies irrespective of the activities they engage in are service economies because they depend on the application of operant resources to be productive (Vargo \& Lusch, 2008). Practitioners' views on inter university resource sharing and networking is in contrast with SD logic. Indeed SD logic argues that, institutions need high quality relationships with their network partners to work in a collaborative manner to co-create superior value by utilising shared resources (Richey, et al., 2010). The survival and growth of institutions are therefore largely dependent on the ability to secure critical resources from network partners (Casciaro \& Piskorski, 2005). Barney et al., (2001) suggest that the growing need for greater effectiveness in business operations has forced more institutions to engage in partnerships leading to increased dependence on each other's resources and capabilities.

\subsubsection{Information Support Systems}

The application of information support systems to facilitate the procurement integration process is an important issue that continues to receive managerial and academic attention (Quesada \& Gonzalez, 2010). Information systems technologies comprise of applications such as electronic data interchange (EDI), inter-organisational systems, e- sourcing, e-procurement, enterprise resource planning (ERP), among others (Dedrick et al., 2008). Among these applications, e-procurement functions are particularly important due to the fact that procurement is one of the most critical functions of supply networks (Quesada \& Gonzalez, 2010). To this effect, the adoption of e-procurement systems may assist institutions to be transparent and efficient, reduce cost, enhance better decision-making, improve supplier performance monitoring, and improve quality of services to customers (Neupane, et al., 2012).

Regarding the use of information support systems in public procurement, practitioners indicate that their respective universities do not use any information support systems in their procurement activities. They acknowledge that they have internet access which they sometimes use to relay information to suppliers already on contracts with them. PbU1 explains: "although our internet is not that reliable, sometimes we are able to use it to send information to suppliers or to enquire about how an existing contract is being executed". The practitioner complains that because most suppliers do not have internet access, they mostly rely on the telephone to communicate with them. When asked about his knowledge of e-procurement, PbU1 responds: "I know or at least have read that it is a system of procurement where the internet is used in carrying out procurement functions such as e-sourcing, e-tendering, e-ordering, and many more". When questioned on whether the university currently implements any e-procurement systems, PbU1 explains: "as far as I'm concerned, there is no policy directive from the PPA on e-procurement, so I think it will be inappropriate or even illegal to use the system". The practitioner hints that he was reliably informed that the PPA was working towards introducing a bill that would allow public institutions to use e-procurement. Addressing questions on the use of EDI, PbU1 explains:

I know it is an electronic system that customers and suppliers use to examine stock levels so 
as to order for replenishments when stock levels reach certain points. The EDI will help avert the problem of occasional stock-outs because we are connected to our key suppliers they will be prompted anytime there is the need to supply goods or services.

When asked whether having key suppliers would not amount to violating the current procurement law, PbU1 who appears confused says: "maybe the EDI is best suited for the private sector". PbU3 explaining the significance of information support systems for procurement indicates that although e-procurement is not being practiced in universities at the moment, he is optimistic that in due course most public institutions would use the concept.

Commenting on how the application of e-procurement can improve procurement performance in the university, PbU3 explains: "you see, for now everything is done manually. ....you have to advertise for suppliers to submit their tenders, and then you evaluate and make a decision. This process involves lots of paper work and it's time consuming too. With e-procurement, I think the university will save cost, and also exercise a higher degree of flexibility". Regarding the use of the EDI, the practitioner argues that because it involves the supplier and the university or customer, it may not be allowed in public universities. The practitioner explains:

To use the EDI, there must be some relationship between the university and suppliers. This is because the supplier should have access to the university's EDI system in order to ascertain inventory levels, and also to be privy to the university's needs. I don't think this can work under our current procurement system.

PbU5 intimates that at the moment his university does not use e-procurement systems, and does not think there are plans to roll-out the system. The practitioner argues that: "we take directives from the PPA on such matters. It is impossible to implement e-procurement without the authorisation of the PPA. So even though our university may wish to introduce e-procurement, we have to wait until there is a legislation or policy mandating us to engage in the practice". In relation to the use of the EDI to facilitate and improve procurement performance, PbU5 expresses optimism that perhaps in future there would be amendments to the current procurement law to enable the incorporation the use of technology in public procurement. PbU5 points out: $\mathrm{PbU} 4$ is of the view that introducing technology into the procurement function will reduce corrupt practices whilst increasing efficiency and saving cost. The practitioner who seems to understand the operations of e-procurement systems explains:

Applying e-procurement systems such as e-sourcing, e-tendering, e-ordering, and e-exchange bring lots of flexibility to the procurement function. I believe these can easily be implemented in our public universities because the principal resource required to implement e-procurement is the internet. At the moment, I know for a fact that all public universities have internet connectivity. The only challenge that I foresee is the situation where local supplier firms don't have access to the internet or have no websites for their businesses.

The practitioner points out that with the current global business environment; it would be difficult to engage business actors from other countries if the nation fails to meet basic technological requirements like e-procurement. He reiterates the fact that: "the technological wind is blowing and Ghana cannot afford to be left behind. I'm very certain e-procurement would be introduced in public universities sooner than later".

The contributions of the internet to e-procurement cannot be overemphasized. E-procurement processes have been transformed by the integration of the internet and supply networks. Web-based information flow between firms has increased the importance of such integration to create effective supply networks (Johnson \& Whang, 2002). Currently suppliers and customers no longer work in isolation and as independent entities as they have become more integrated with information systems providing the platform for integrated supply networks (Monczka, et al, 2002). Indeed, researchers are optimistic on the level of savings that can be achieved through full implementation of e-procurement strategies such as: EDI, ERP, and inter-organisation systems among others (Aboelmaged, 2010).

\section{Conclusion}

The study has revealed that a proper integration of SD logic into public procurement practices could lead to performance improvement. This is possible because a strong and long-term relationship between universities and firms result in a better understanding of the needs of each other. This implies that firms are able to make value propositions that suit universities' needs. In other words, a strong collaboration between actors in a business engagement culminates into performance improvement as both parties strive to fulfill their obligations for their mutual benefit. This position is consistent with FP6 and FP7 of SD logic, which argue that value-creating resources are not confined to the firm. Suggesting that customers, supplier firms, and other stakeholders 
collaborate to create value. Thus, the logic asserts that value is co-created with institutions and firms through strong relationships and collaborations. However, the FPs contrast current procurement practices in Ghana as prohibitions are placed on customer-supplier relationship building and management, meaning that there is the tendency suppliers' may not make quality value propositions resulting in fallen performance standards.

In relation to resource integration and networking, it is significant to stress that, this has become the hallmark of most modern businesses. Businesses integrate their resources and network with others in order to benefit from each other's unique capabilities. This is important because although all parties to business engagements possess some kind of unique resources, the uniqueness of each party's resources mean there is the need to exchange one unique service for another unique service. It is therefore essential that organizations integrate their resources and network with others in order to share each other's unique resources. SD logic's position on resource integration and networking as spelt out in FP9 suggests that all social and economic actors are resource integrators because value co-creation results from networks of collaborative relationships where one unique resource is exchanged for another. Exchanging one unique resource for another enables parties to have access to complementary resources to better deliver quality value propositions leading to improvements in outputs. Conversely, because all universities are independent procurement entities with specified thresholds, varied vision and policy directions, there exist minimal levels of resource integration and networking.

On the issue of availability and application of information support systems for public procurement, the study revealed that the lack of procurement technologies is further compounded by policies that make their adoption almost impossible. Technologies such as EDI, ERP, inter-organisational systems, cannot be used in the public sector because conditions under which they can be used among others involve relationship building, networking, resource integration and information sharing, which the current procurement system does not support. The fact that the use of these procurement technologies may lead to improved transparency and efficiency, reduce costs, enhance better decision-making, improve supplier performance monitoring, and the quality of services to customers mean that neglecting their usage may negatively affect procurement performance in Ghanaian universities.

\section{References}

Aboelmaged, M. G. (2010). Predicting e-procurement adoption in a developing country: an empirical integration of technology acceptance model and theory of planned behaviour. Industrial Management \& Data Systems, 110(3), 392-414. https://doi.org/10.1108/02635571011030042

Al-Turki, M. U., Duffuaa, S., Ayar, T., \& Demirel, O. (2008). Stakeholders integration in higher education: supply chain approach. European Journal of Engineering Education, 33(2), 211-219. https://doi.org/10.1080/03043790801980136

Anvuur, A., \& Kumaraswamy, M. M. (2006). Taking forward public procurement reforms in Ghana Paper presented at the CIB W107 Construction in developing economies international symposium.

Ballantyne, D., \& Varey, R. J. (2008). The service-dominant logic and the future of marketing. Journal of the Academy of Marketing Science, 36(1), 11-14. https://doi.org/10.1007/s11747-007-0075-8

Barney, J. B. (1991). Firm resources and sustained competitive advantage. Journal of Management, 17, 99-120. https://doi.org/10.1177/014920639101700108

Barney, J., Wright, M., \& Ketchen, J. D. Jr. (2001). The resource-based view of the firm: ten years after 1991. Journal of Management, 27, 625-641. https://doi.org/10.1177/014920630102700601

Bemelmans, J., Voordijk, H., Vos, B., \& Buter, J. (2011). Assessing buyer-supplier relationship management: Multiple case studies in the Dutch construction industry. Journal of Construction Engineering and Management, 138(1), 163-176. https://doi.org/10.1061/(ASCE)CO.1943-7862.0000418

Burt, D. N., Dobler, D. W., \& Starling, S. L. (2003). World-class supply chain management: The key to supply chain management (7th ed.). New York: McGraw-Hill.

Casciaro, T., \& Piskorski, M. J. (2005). Power imbalance, mutual dependence, and constraint absorption: A closer look at resource dependence theory. Administrative Science Quarterly, 50(2), 167-199. https://doi.org/10.2189/asqu.2005.50.2.167

Christopher, M., \& Gaudenzi, B. (2009). Exploiting knowledge across networks through reputation management. Industrial Marketing Management, 38, 191-197. https://doi.org/10.1016/j.indmarman.2008.12.014

Comm, L. C., \& Mathaisel, F. X. D. (2008). Sustaining higher education using Wal-Mart's best supply chain management practices. International Journal of Sustainability in Higher Education, 9(2), 183-189. 
https://doi.org/10.1108/14676370810856323

Cope, J. (2005). Researching entrepreneurship through phenomenological inquiry: philosophical and methodological issues. International Small Business Journal, 23(2), 163-189. https://doi.org/10.1177/0266242605050511

Dedrick, J., Xu, S. X., \& Zhu, K. X. (2008). How does information technology shape supply-chain structure? Evidence on the number of suppliers. Journal of Management Information Systems, 25(2), 41-72. https://doi.org/10.2753/MIS0742-1222250203

Dey, I. (1993). Qualitative data analysis: A user-friendly guide for social scientists. Routledge. https://doi.org/10.4324/9780203412497

Dza, M. (2013). Applying Service-dominant Logic Into the Procurement Function in Ghanaian Universities (Doctoral dissertation, Griffith University).

Dza, M., Fisher, R., \& Gapp, R. (2013). Procurement reforms in Africa: The strides, challenges, and improvement opportunities. Public Administration Research, 2(2), 49. https://doi.org/10.5539/par.v2n2p49

Flint, D. J. (2006). Innovation, symbolic interaction and customer valuing: thoughts stemming from a service-dominant logic of marketing. Journal of Marketing Theory, 6(3), 349-362. https://doi.org/10.1177/1470593106066796

Flynn, B. B., Huo, B., \& Zhao, X. (2010). The impact of supply chain integration on performance: a contingency and configuration approach. Journal of Operations Management, 28(1), 58-71. https://doi.org/10.1016/j.jom.2009.06.001

Goldsworthy, J. (2008). Research grant mania. Australian Universities Review, 50(2), 17-24.

Goulding, C. (2005). Grounded theory, ethnography and phenomenology: A comparative analysis of three qualitative strategies for marketing research. European Journal of Marketing, 39(2), 294-308. https://doi.org/10.1108/03090560510581782

Gummesson, E., Lusch, R. F., \& Vargo, S. L. (2010). Transitioning from service management to service-dominant logic: observations and recommendations. International Journal of Quality and Service Sciences, 2(1). https://doi.org/10.1108/17566691011026577

Immerwahr, J., \& Johnson, J. (2007). Squeeze play: how parents and the public look at higher education today. The National Center for Public Policy and Higher Education.

Johnson, M., \& Whang, S. (2002). E - business and supply chain management: an overview and framework. Production and Operations Management, 11(4), 413-423. https://doi.org/10.1111/j.1937-5956.2002.tb00469.x

Li, W., Humphreys, P. K., Yeung, A. C. L., \& Cheng, E. T. C. (2007). The impact of specific supplier development efforts on buyer competitive advantage: an empirical model. International Journal of Production Economics, 106(1), 230-247. https://doi.org/10.1016/j.ijpe.2006.06.005

Lusch, R. F. (2011). Re-framing supply chain management: A service-dominant logic perspective. Journal of Supply Chain Management, 47(1), 14-18. https://doi.org/10.1111/j.1745-493X.2010.03211.x

Lusch, R. F., \& Vargo, S. L. (2012). The forum of markets and marketing (FMM): advancing service-dominant logic. Marketing Theory, 12(2), 193-199. https://doi.org/10.1177/1470593111429509

Lusch, R. F., \& Webster, F. E. (2011). A stakeholder-unifying, co-creation philosophy for marketing. Journal of Macro marketing, 3(2), 129-134. https://doi.org/10.1177/0276146710397369

Lusch, R. F., Vargo, S. L., \& Tanniru, M. (2010). Service, value networks and learning. Academy of Marketing Science, 38, 19-31. https://doi.org/10.1007/s11747-008-0131-z

Makkar, U., Gabriel, O. E., \& Tripathi, K. S. (2008). Value chain for higher education sector - case studies of India and Tanzania. Journal of Services Research, (Special Issue), 183-200.

Mandiyambira, R. (2012). Managing supplier relationships to improve public procurement performance. African Journal of Business Management, 6(1), 306-312. https://doi.org/10.5897/AJBM11.2197

Ministry of Finance. (2003). Procurement Reform Proposal, a component of the Public.

Monczka, R., Trent, R., \& Handfield, R. (2002). Purchasing and Supply Chain Management (2nd ed.). South-Western, Thomson Learning. 
Narasimhan, R., \& Kim, S. W. (2002). Effect of supply chain integration on the relationship between diversification and performance: evidence from Japanese and Korean firms. Journal of Operations Management, 20(3), 303-323. https://doi.org/10.1016/S0272-6963(02)00008-6

Neupane, A., Soar, J., Vaidya, K., \& Yong, J. (2012, August). Role of public e-procurement technology to reduce corruption in government procurement. In Proceedings of the 5th International Public Procurement Conference (IPPC5) (pp 304-334). Public Procurement Research Center.

Normann, R. (2001). Reframing business: when the map changes the landscape. Chichester: Wiley.

O'Brien, E. M., \& Kenneth, R. D. (1996). Educational supply chain: a tool for strategic planning in tertiary education? Marketing Intelligence \& Planning, 14(2), 33-43. https://doi.org/10.1108/02634509610110787

PPA. (2007). Public Procurement Authority (PPA) Annual Report. Republic of Ghana, pp.18.

Prahalad, C. K., \& Ramaswamy, V. (2004). The future of competition: Co-creating unique value with customers. Boston, MA: Harvard Business School Press.

Prahinski, C., \& Benton, W. (2004). Supplier evaluations: communication strategies to improve supplier performance. Journal of Operations Management, 22(1), 39-62. https://doi.org/10.1016/j.jom.2003.12.005

Quesada, G., González, M. E., Mueller, J., \& Mueller, R. (2010). Impact of e-procurement on procurement practices and performance. benchmarking: An International Journal, 17(4), 516-538.

Richey Jr, R. G., Tokman, M., \& Dalela, V. (2010). Examining collaborative supply chain service technologies: a study of intensity, relationships, and resources. Journal of the Academy of Marketing Science, 38(1), 71-89. https://doi.org/10.1007/s11747-009-0139-z

Spohrer, J., Maglio, P. P., Bailey, J., \& Gruhl, D. (2007). Steps towards a science of service systems Paper presented at the International Conference on Information Reuse and Integration. https://doi.org/10.1109/MC.2007.33

Spohrer, J., Vargo, L. S., Caswell, N., \& Maglio, P. P. (2008). The service system is the basic abstraction of service science. Paper presented at the 41st Hawaii International Conference on System Sciences, Hawaii. https://doi.org/10.1109/HICSS.2008.451

Strauss, A., \& Corbin, J. (1998). Basics of qualitative research techniques. Sage publications.

Strauss, A., \& Corbin, J. M. (1990). Basics of grounded theory methods. Beverly Hills, CA.: Sage.

Swink, M., \& Nair, A. (2007). Capturing the competitive advantage of AMT: design.

Terpend, R., Tyler, B. B., Krause, D. R., \& Handfield, R. B. (2008). Buyer-supplier relationships: derived value over two decades. Journal of Supply Chain Management, 44(2), 28-55. https://doi.org/10.1111/j.1745-493X.2008.00053.x

Terzi, C., \& Posta, I. (2011). Procurement reforms in the United Nations system Geneva: United Nations.

Thai, K. V. (2008). Measuring losses to public procurement corruption: the Uganda case. Paper presented at the 3rd International Public Procurement Conference Proceedings.

Thomas, A., Abdoulaye, K., Frannie, L., \& Sithabile, M. (2007). Trends in public procurement in Africa: Opportunities and Challenges of capacity building interventions. Retrieved from http://siteresources.worldbank.org/informationandcommunicationanttechnologies/Resources/eGP-in-Africa. pdf

Tokman, M., \& Beitelspacher, L. S. (2011). Supply chain networks and service-dominant logic: suggestions for future research. International Journal of Physical Distribution \& Logistics Management, 41(7), 717-726. https://doi.org/10.1108/09600031111154152

van Weele, A. J. (2006). Purchasing and Supply Chain Management: Infotrac Card: Thomson Learning EMEA, Limited.

Vargo, S. L, Maglio, P. P., \& Akaka, A. M. (2008). On value and value co-creation: A service systems and service logic perspective. European Management Journal, 26, 145-152. https://doi.org/10.1016/j.emj.2008.04.003

Vargo, S. L. (2008). Customer Integration and Value Creation: Paradigmatic Traps and Perspectives. Journal of Service Research, 11, 211-215. https://doi.org/10.1177/1094670508324260

Vargo, S. L., \& Lusch, F. R. (2006). The Service-Dominant Logic of Marketing: Dialog, Debate, and Directions.

Vargo, S. L., \& Lusch, F. R. (2008). From goods to service(s): divergences and convergences of logics. 
Industrial Marketing Management, 37, 254-259. https://doi.org/10.1016/j.indmarman.2007.07.004

Vargo, S. L., \& Lusch, F. R. (2010). "Relationship" in Transition: An introduction to the special issue on relationship and service-dominant logic. Journal of Business Market Management, 4, 167-168. https://doi.org/10.1007/s12087-010-0042-4

Wittig, W. (1999). Building value through public procurement: a focus on Africa. International Trade Centre.

World Bank. (1996). Country procurement assessment report for Ghana. Washington, DC.

Yazdanparast, A., Manuj, I., \& Swartz, S. M. (2010). Co-creating logistics value: a service-dominant logic perspective. International Journal of Logistics Management, 21(3), 375-403. https://doi.org/10.1108/09574091011089808

Yin, R. K. (2009). Case study research: design and methods (4th ed., Vol. 5). SAGE Publication, Inc.

Zhao, X., Huo, B., Flynn, B. B., \& Yeung, J. (2008). The impact of power and relationship commitment on the integration between manufacturers and customers in a supply chain. Journal of Operations Management, 26(3), 368-388. https://doi.org/10.1016/j.jom.2007.08.002

Zhao, X., Huo, B., Selen, W., \& Yeung, J. H. Y. (2011). The impact of integration and relationship commitment on external integration. Journal of Operations Management, 29(1/2), 17-32. https://doi.org/10.1016/j.jom.2010.04.004

\section{Copyrights}

Copyright for this article is retained by the author(s), with first publication rights granted to the journal.

This is an open-access article distributed under the terms and conditions of the Creative Commons Attribution license (http://creativecommons.org/licenses/by/4.0/). 